\title{
Kreativitas dan Motivasi Belajar Mahasiswa dalam Implementasi Blended Learning Berbasis Bali
}

\section{Putu Oktap Indrawan ${ }^{1 *}$, Gede Arna Jude Saskara², I Komang Wisnu Budi Wijaya ${ }^{3}$}

${ }^{1}$ Prodi D3 Manajemen Infromatika, Politeknik Ganesha guru Indonesia

${ }^{2}$ Prodi D3 Teknik Komputer, Politeknik Ganesha guru Indonesia

${ }^{3}$ Prodi S1 PGSD, IHDN Denpasar

\section{A R T I C L E I N F O}

Article history:

Received 19 April 2019

Received in revised form 10 May 2019

Accepted 12 June 2019

Available online 25 July 2019

Kata Kunci:

Blended Learning, BALI

Keywords:

Blended Learning, BALI

\begin{abstract}
A B S T R A K
Tujuan penelitian ini adalah untuk mengetahui: (1) implementasi Blended Learning berbasis BALI; (2) kreativitas mahasiswa pada implementasi Blended Learning berbasis BALI; (3) motivasi belajar mahasiswa pada implementasi Blended Learning berbasis BALI. Metode yang digunakan dalam penelitian ini adalah diskriptif kualitatif. Hasil penelitian menunjukkan: (1) implementasi Blended Learning berbasis BALI dilakukan melalui proses (a) persiapan tema, pembuatan kelas maya schoology, dan pembuatan form penilaian presentasi diskusi, (b) proses pembelajaran Blended Learning berbasis BALI; dan (c) penutup berupa penyimpulan dan evaluasi hasil pembelajaran; (2) implementasi Blended Learning berbasis BALI mampu mendorong kreativitas mahasiswa dengan adanya indicator-indikator deskriptif hasil pengamatan dalam proses pembelajaran; (3) implementasi Blended Learning berbasis BALI mampu mendorong motivasi belajar mahasiswa dengan teramatinya indikator sesuai dengan teori Schwtzgebel dan Kalb. Berdasarkan temuan hasil penelitian disarankan untuk peneliti selanjutnya mengggunakan subjek penelitian yang lebih banyak dengan metode yang berbeda misalnya eksperimen, penelitian tindakan, pengembangan ataupun metode campuran (mix method).
\end{abstract}

\section{A B S T R A C T}

The purpose of this study is to find out: (1) the implementation of BALI-based Blended Learning; (2) student creativity in the implementation of BALI-based Blended Learning; (3) student learning motivation on the implementation of BALI-based Blended Learning. The method used in this research is descriptive qualitative. The results showed: (1) the implementation of BALI-based Blended Learning was carried out through the process of (a) theme preparation, making schoology virtual classes, and making discussion presentation assessment forms, (b) the BALI-based Blended Learning process; and (c) closing in the form of a conclusion and evaluation of learning outcomes; (2) the implementation of BALI-based Blended Learning is able to encourage student creativity with the presence of descriptive indicators of observations in the learning process; (3) the implementation of BALI-based Blended Learning is able to encourage student learning motivation by observing indicators in accordance with the theories of Schwtzgebel and Kalb. Based on the findings of the research it is recommended that future researchers use more research subjects with different methods such as experiments, action research, development or mixed methods.

\footnotetext{
* Corresponding author.

E-mail addresses: oktap8indrawan@gmail.com (I Putu Oktap Indrawan)
} 


\section{Pendahuluan}

Fasilitas belajar berupa ruang belajar, computer, dan wifi merupakan sebuah peluang untuk melaksakan blended learning. Selain itu, mahasiswa sebagian besar memiliki komputer, smartphone, dan menggunakan data internet per bulan. Blended learning telah diimplementasikan untuk beberapa mata kuliah di Politeknik Ganesha Guru, salah satunya Mata Kuliah Agama Hindu. Berdasarkan hasil wawancara dengan mahasiswa akan mengambil Mata Kuliah Agama Hindu pembelajaran Agama Hindu yang diperoleh sebelumnya memiliki karakteristik: (1) materi yang disajikan sebagian besar masih berupa materi teoritis yang kurang kontekstual terhadap kehidupan mahasiswa sehari-hari; (2) pembelajaran Mata Kuliah Agama Hindu sebagian besar dogma yang mesti diyakini dan tidak perlu ada pembuktian ilmiah; (3) adanya sekat jelas antara Ilmu Pengetahuan Agama dan Ilmu Pengetahuan Ilmiah yang seakan tidak saling terhubung; (4) pengajar lebih sering membahas tentang ritual/upakara dan banten saja; (5) pembelajaran cenderung teacher center. Oleh sebab itu mahasiswa membutuhkan proses pembelajaran Mata Kuliah Agama Hindu yang memiliki karakteristik: (1) materi kontekstual yang menyentuh kehidupan sehari-hari; (2) pembelajaran yang mengarah pada kesadaran bukan hanya sekedar dogma; (3) membangun keselarasan antara ilmu pengetahuan ilmiah dengan pengetahuan agama, yang saling menguatkan; (4) materi menekankan etika dan filsafat universal yang dapat diimplementasikan dalam kehidupan sehari-hari; (5) pembelajaran yang bersifat student center.

Berdasarkan kebutuhan tersebut peneliti mencoba mengimplementasikan pembelajaran yang berbasis BALI, yang merupakan akronim dari B (Berpikir, Berkata, dan atau Berbuat), A (Aktual), L (Literatif), dan I (Integratif). Berpikir, berkata, dan atau berbuat lebih mengarah pada hal yang dilakukan mahasiswa saat proses pembelajaran, mengacu pada kearifan lokal di Agama Hindu Bali Tri Kaya Parisudha. Trikaya parisudha terdiri atas manacika (berpikir yang benar), kayika (berbuat benar), dan wacika (berkata yang benar) (Indrawan, 2019; Adnyana \& Citrawathi, 2017). Aktual bermakna mempelajari materi, masalah, atau isu terkini/ter-update dan nyata. Aktual berdasarkan KBBI bermakna: (1) betul-betul terjadi/sesungguhnya, (2) peristiwa yang sedang menjadi pembicaraan orang banyak; dan atau (3) masih baru/hangat. Literatif artinya pembahasan harus mengacu berbagai sumber belajar/literasi yang mendukung. Literatif mendorong mahasiswa untuk membiasakan diri membaca berbabagai sumber. Hal tersebut bertujuan meningkatkan minat baca mahasiswa. Berdasarkan hasil penelitian CCSU Indonesia masuk urutan ke-44 dikalahkan oleh Peru [1]. Integratif artinya belajar dengan melihat dari berbagai sudut pandang dengan mengintegrasikan berbagai sumber kajian maupun bidang ilmu. Sehingga melalui pendekatan ini diharapkan mahasiswa mampu lebih banyak belajar secara mandiri, dimana dosen berperan sebagai fasilitator saja (student center).

Guna mengefisienkan proses pembelajaran berbasis BALI, pembelajaran dikemas dalam bentuk blended learning. Blended learning merupakan gabungan metode pembelajaran tradisional dan pembelajaran daring [2]. Blended learning memungkinkan proses tatap muka antara dosen dan mahasiswa dapat melalui tatap muka di kelas ataupun melalui daring (online) [3]. Proses pembelajaran blended learning iberbasis BALI diharapkan mampu meningkatkan daya kreativitas mahasiswa dan kemampuan berpikir kritis mahasiswa.

PBM yang meningkatkan daya kreativitas yang tinggi menurut Ali dan Anzori (2004) memenuhi apek-aspek pokok individu kreatif antara lain: (1) mampu meilhat persoalan/maslah dari berbagai sudut pandang; (2) memiliki kemampuan berpikir menyebar yang memungkinkan mencari berbagai jawaban yang berbeda; (3) fleksibilitas konseptual adalah kemampuan untuk secara spontan mengganti cara pandang dan pendekatan kerja berbeda; (4) Originalitas merupakan keterampilan mengungkapkan ide, gagasan, pemecahan, cara kerja yang tidak biasa dan jarang bahkan mengejutkan; (5) menyukai kompleksitas yang menantang, yang terhubung dengan logika-logika tertentu; (6) ekosistem belajar yang merangsang timbulnya kreativitas individu; (7) memiliki multi keterampilan dan minat dalam berbagai bidang; dan (8) dapat menikmati kehidupan dari berbagai sudut pandang. Blended learning mengasah mahasiswa dalam mengembangkan keterampilan menggunakan internet melalui kelas maya schoology dan google form, serta mempresentasikan dan mendiskusikan makalah yang mereka buat dengan pendekatan BALI (Belajar Aktual, Literatif, dan Integratif) yang tentunya meningkatkan kreativitas mereka dalam berpikir dan meninjau tema dari berbagai sudut pandang dan sumber.

Blended learning berbasis BALI diharapkan juga mampu meningkatkan motivasi belajar mahasiswa. Tema yang harus dibahas kelompok mahasiswa dengan contoh kejadian aktual dari berbagai sumber (literatif) secara holistik dari berbagai sudut pandang (integratif) diharapkan mampu memberikan tantangan mahasiswa untuk menggali lebih dalam materi dan memandang isu dari sudut pandang yang lebih banyak dan luas. Keingintahuan berbagai sudut pandang tersebut diharapkan mampu memdorong penggerak psikis didalam pebelajar yang menimbulkan kegiatan belajar demi mencapai suatu tujuan [4]. Motivasi belajar merupakan dorongan internal dan eksternal pada pebelajar berupa 
hasrat dan keinginan berhasil, dorongan dan kebutuhan dalam belajar, harapan dan cita-cita masa depan, penghargaan dalam belajar, serta lingkungan belajar yang kondusif [5].

Tujuan penelitian ini adalah untuk mengetahui: (1) implementasi Blended Learning berbasis BALI; (2) kreativitas mahasiswa pada implementasi Blended Learning berbasis BALI; (3) motivasi belajar mahasiswa pada implementasi Blended Learning berbasis BALI.

\section{Metode}

Metode yang digunakan dalam penelitian ini adalah diskripsi kualitatif. Deskripsi kualitatif artinya mendiskripsikan secara kualitatif program dan atau pengalaman di lingkungan penelitian [6]. Subjek penelitian ini adalah 7 (tujuh) mahasiswa yang mengambil Mata Kuliah Agama Hindu. Data dikumpulkan dari April sampai dengan Mei 2019 di Politeknik Ganesha Guru. Data dikumpulkan melalui metode observasi, pengisian kuesioner dan test. Analisis dan interpretasi data melibatkan pengujian disiplin, pemahaman kreatif, dan perhatian yang cermat pada tujuan studi penelitian.

\section{Hasil dan Pembahasan}

\section{A. Implementasi Blended Learning berbasis BALI}

Instructional model mestinya mempertimbangkan kesesuaian antara model pendidikan yang diselenggarakan, teknik dan metode pembelajaran mata kuliah, serta ketersediaan sarana dan prasarana pembelajaran.

Proses persiapan implementasi dilakukan oleh peneliti dengan mengumpulkan tema yang akan dibahas dalam Blended Learning berbasis BALI. Tema akan dibahas mahasiswa dalam kelompok kecil yang terdiri dari 2 atau 3 orang. Tema yang akan dibahas antara lain: (1) teknologi Informasi dan Agama Hindu; (2) pemerintahan dan kepemimpinan berbasis Hindu; dan (3) filosofi banten dan implementasi dalam kehidupan. Tema tersebut di unggah ke dalam kelas maya yang telah disepakati untuk digunakan yaitu Schoology.

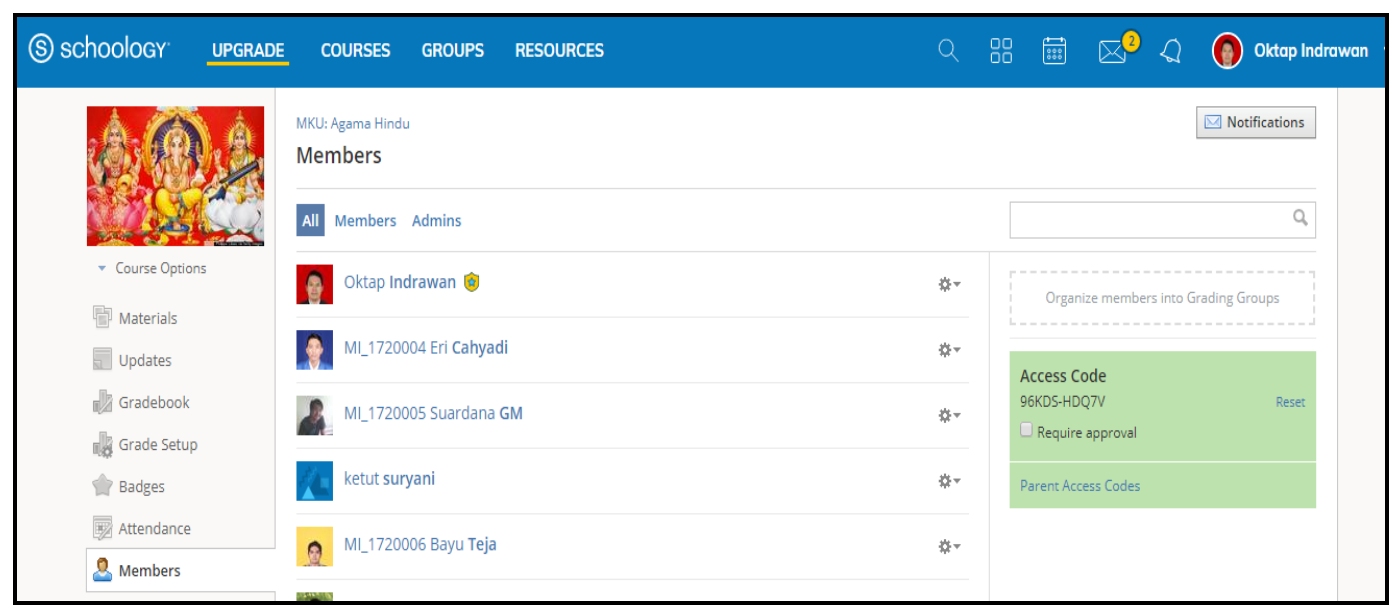

Gambar 1. Courses Mata Kuliah Agama Hindu di Schoology

Masing-masing kelompok memperoleh satu tema untuk dibahas. Kelompok diberikan waktu seminggu untuk menyiapkan materi sesuai tema diberikan dengan metode BALI, belajar aktual, literatif dan integratif. Setiap minggu salah satu kelompok satu kelompok mempresentasikan materi sesuai tema yang dibahas dalam kelompoknya, kemudian dilakukan diskusi terkait tema tersebut.

Presentasi kelompok I tentang teknologi informasi dan Agama Hindu. Kelompok I presentasi dan diskusi tentang perubahan gaya hidup yang muncul di media social misalnya facebook dan Instagram dimana orang-orang: (1) berlomba-lomba menunjukkan diri di dunia maya, (2) menggunakan dunia maya sebagai media berdoa, (3) mengeluh, (4) berkomunikasi dengan orang-orang jauh dan malah tidak dikenal, (5) media untuk bertengkar, membuli, dan saling mencaci; (6) mengekspose ranah pribadi; dan (7) penyebaran berita hoaks. Tentunya hal-hal tersebut bertentangan dengan beberapa filosofi Hindu salah satunya meningkatkan sifat-sifat asuri sampat (sifat keraksasaan di dalam diri). Selain itu, media sosial diyakini menyebabkan "orang semakin dekat dengan orang yang jauh dan semakin jauh dengan orang yang dekat". Banyak orang terlalu asik dengan media sosial sehingga melupakan swadharma yang harus dilakukan bain di rumah tangga maupun di dunia kerja. Media sosial juga menyebabkan tidak sadar 
terhadap waktu dan tempat yang dapat menyebabkan kecelakaan. Hal tersebut juga mengganggu kesehatan tri sarira, khususnya stula sarira badan fisik akibat kelelahan atau paparan radiasi. Sedangkan, berita hoaks, informasi tentang dunia horor, kekerasan, dan atau pornografi dapat merusak stula sarira berupa gangguan psikologis seperti ketakutan, nafsu yang tidak terkontrol, dan pemikiran-pemikiran yang tidak logis yang diakibatkan oleh paparan hoaks yang berulang-ulang.

Ketergantungan terhadap teknologi, khususnya penggunaan sosial media dan smartphone menyebabkan banyak orang kehilangan kesadaran melaksanakan swadharma, misalnya orang tua yang mestinya memprioritaskan perhatian terhadap anak-anak malah memprioritaskan perhatian pada media sosial di smartphone, karena kecanduan sosial media. Selain itu orang sudah tergantung pada google, mulai dari pencarian, google map, g-mail, sampai google asisten. Perubahan era revolusi industri berpengaruh terhadap pola kehidupan masyarakat (society), khususnya era revolusi industry 4.0.

Internet sebagai pusat informasi seperti pedang bermata ganda yang berdampat positif dan juga negatif, khususnya terhadap moralitas dan etika. Model yang salah yang menjadi panutan bagi generasi muda akan membawa mereka terjerumus pada moralitas dan etika yang rendah. Hoaks dan bullying di dunia maya yang berkembang sebagai rajapisuna atau fitnah yang merugikan orang lain, yang menghasilkan penilaian negatif terhadap orang yang belum tentu negatif. Seks bebas, foto-foto, dan video tidak senonoh sangat mudah diakses oleh warganet yang dapat mendorong tindakan dratikrama (pemerkosaan/berzinah).

Peluang pengembangan gerakan kesadaran dalam penggunaan teknologi informasi berbasis hindu khususnya sosial media berbasis Hindu dibahas sebagai berikut.

1) Bijak berprilaku di dunia maya dengan menerapkan Tri Kaya Parisudha yaitu berpikir, berkata, dan bebuat yang baik.

2) Tidak melakukan bullying yang menyebabkan luka psikologis terhadap orang lain dengan menerapkan tatwamasi. Berperilaku baik, menghargai, dan menghormati orang lain sebagaimana kita menghormati dan menghargai diri sendiri.

3) Memberikan contoh yang baik sehingga menjadi tauladan bagi banyak orang dengan mempublikasikan kegiatan yang mengimplementasikan "Sagilik-Saguluk Salunglung Sabayantaka, Paras-Paros Sarpanaya, Saling Asah, Asih, Asuh" yang artinya bersatu-padu, saling menghargai pendapat orang lain, dan saling mengingatkan, saling menyayangi, saling tolong-menolong.

4) Pengembangan memprioritaskan swadharma (kewajiban pribadi) dan dharma negara misalnya cinta tanah air, sadar pajak, dan sebagainya.

Pada presentasi II yang bertema "Pemerintahan dan kepemimpinan berbasis Hindu" dibahas tentang definisi kepemimpinan, konsep-konsep kepemimpinan berbasis Hindu, pola kepemimpinan saat ini dan solusi mengatasi permasalahan penyimpangan kepemimpinan. Kepemimpinan diartikan sebagai kemampuan untuk mengkoordinir dan mengerahkan orang-orang serta golongan-golongan untuk tujuan tertentu. Sifat-sifat pemimpin ideal dalam Hindu dapat ditinjau dari filsafat kepemimpinan misalnya: sad wananing rajaniti, catur kotamaning nrpati, tri upaya sandhi, panca upaya sandhi, nawa natya, panca dasa pramiteng prabhu, sad upaya guna, panca satya, dan asta brata.

Kelompok II membahas tentang permasalahan aktual kepemimpinan dalam pemerintahan yang di hadapi saat ini, salah satunya adalah masih adanya praktik korupsi, kolusi, dan nepotisme (KKN). Praktik korupsi masih banyak dengan adanya temuan OTT oleh KPK, namun praktik kolusi dan nepotisme sangat sulit untuk di deteksi terutama dalam pengurusan perijinan, surat menyurat, dan penerimaan tenaga kerja kerja. Adanya kesenjangan antara minoritas dan mayoritas dalam kesempatan menduduki jabatan. Selain itu, masih muncul beberapa oknum yang mementingkan kepentingan pribadi/kelompok dibandingkan kepentingan negara dalam melaksanakan tugas kepemimpinan. Berdasarkan hal tersebut diperlukan kontrol system yang lebih kuat untuk membatasi penyimpangan tersebut, antara lain dengan: (1) penguatan peraturan/perundang-undangan yang mengatur system pemerintahan; (2) LSM yang membantu pengawasan kebijakan-kebijakan pemerintah; (3) pendidikan karakter yang ditanamkan sejak dini.

Sifat kepemimpinan Hindu yang dapat diimplementasikan untuk mengatasi permasalahanpermasalahan tersebut salah satunya adalah panca satya. Panca satya antara lain satya: (1) Hrdaya (jujur terhadap diri sendiri/setia dalam hati); (2) wacana (jujur dalam perkataan/setia dalam ucapan); (3) samaya (setia pada janji); (4) mitra (setia pada sahabat); dan (5) Laksana (jujur dalam perbuatan). Pada saat panca satya diimplementasikan pasti KKN dapat diatasi, tidak terjadi penyelewengan dana, penilaian yang objektif, dan penempatan orang yang tepat sesuai dengan kemampuanya di pemerintahan.

Presentasi III membahas tema tentang "Filosofi Banten dan implementasi dalam kehidupan". Banten merupakan implementasi dari ajaran bakti marga yang bersumber dari Bagavad Gita IX.26. Banten juga termasuk yantra atau simbol-simbol yang penuh arti, banten sebagai sarana menyampaikan filosofi 
Hindu melalui seni dan yadnya, misalnya penyeneng menyimbolkan kehidupan yang seimbang antara sekala (duniawi) dan niskala (rohani). Bhuawan Tatwa Rsi Markandya menyatakan banten dikembangkan oleh Rsi Markandya berdasarkan hasil semedi di gunung raung. Banten ada awalnya berupa sesajen sederhana dengan simbol-simbol ajaran agama Hindu. Saat ini banten berkembang menjadi sangat banyak, pengembanganya berbeda sesuai dengan sima desa (tempat), kala (waktu) dan patra (keadaan). Banten berkembang berdasarkan interpretasi dan improvisasi masyarakat pada suatu wilayah dalam kurun waktu tertentu yang disesuaikan dengan situasi/keadaan. Perbedaan interpretasi berdasarkan desa, kala, dan patra kadang menyebabkan standar khusus implementasi penggunaan banten. Sehingga, apabila ada upacara atau yadnya yang melibatkan lebih dari satu daerah misalnya perkawinan antar kabupaten perlu adanya kordinasi terkait banten, agar tidak terjadi kesalahpahaman. Banten merupakan salah satu asset budaya Bali yang harus dipertahankan karena: (1) banten mempermudah masyarakat dalam mempelajari filosofi Hindu; (2) banten sebagai seni menjadi daya tarik tersendiri untuk pariwisata Bali, khususnya pariwisata yang menunjukkan prosesi yadnya ataupun pariwisata spiritual Bali; dan (3) banten memiliki peran dalam perputaran ekonomi masyarakat dan juga pelestarian jenis tanaman yang dibutuhkan dalam pembuatan banten.

Demikianlah hasil presentasi diskusi yang dibahas di dalam kelas oleh mahasiswa. Dalam proses presentasi diskusi kelompok mahasiswa yang tidak presentasi menilai kelompok yang presentasi, penilaian dilakukan secara daring menggunakan google form.

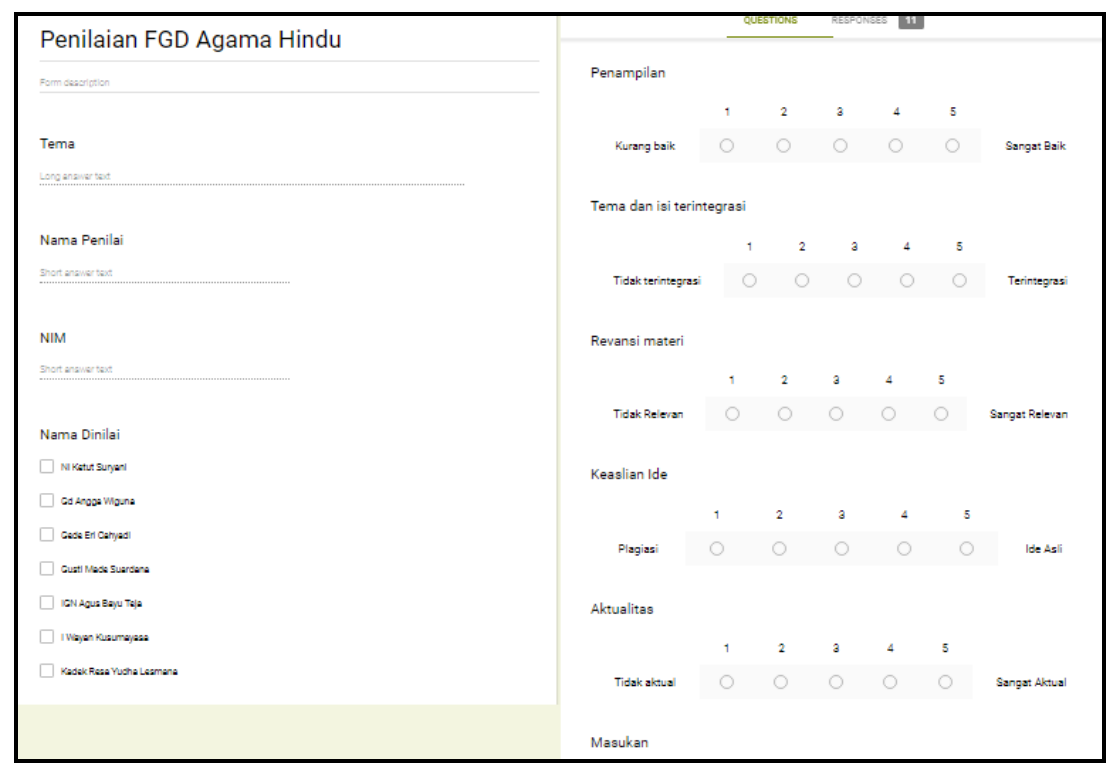

Gambar 2. Form Penilain Presentasi

Penilaian teman sejawat yang dilakukan secara daring selain menghasilkan penilaian yang objektif dan terbuka, selain dari penilaian oleh dosen, juga melatih keterampilan evaluasi mahasiswa. Berdasarkan pembahasan tersebut sudah muncul pembahasan yang bersifat integratif, yang diperoleh dari berbagai sumber, meskipun kebanyakan sumber yang dikutip masih bersumber dari website bukan dari buku atau jurnal.

Pada setiap penutup perkuliahan dosen menyimpulkan dan memberikan feed back terhadap hasil presentasi diskusi mahasiswa. Setelah, semua kelompok melakukan presentasi, mahasiswa diwajibkan mengikuti tes secara daring berupa soal essay (Gambar 3). 


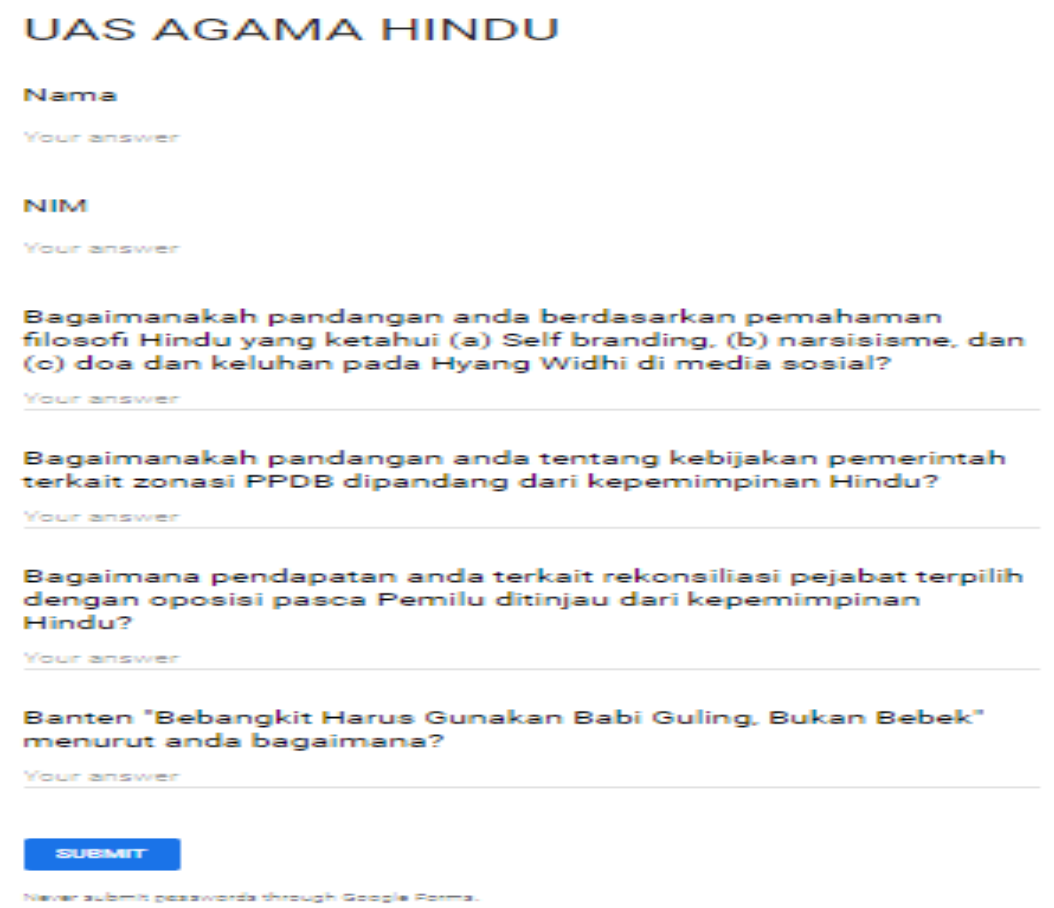

Gambar 3. Tes Pasca Presentasi Diskusi

Jawaban hasil pengisian tes, dibagikan melalui update schoology yang kemudian dinilai secara daring menggunakan google form oleh teman sejawatnya (Gambar 4).

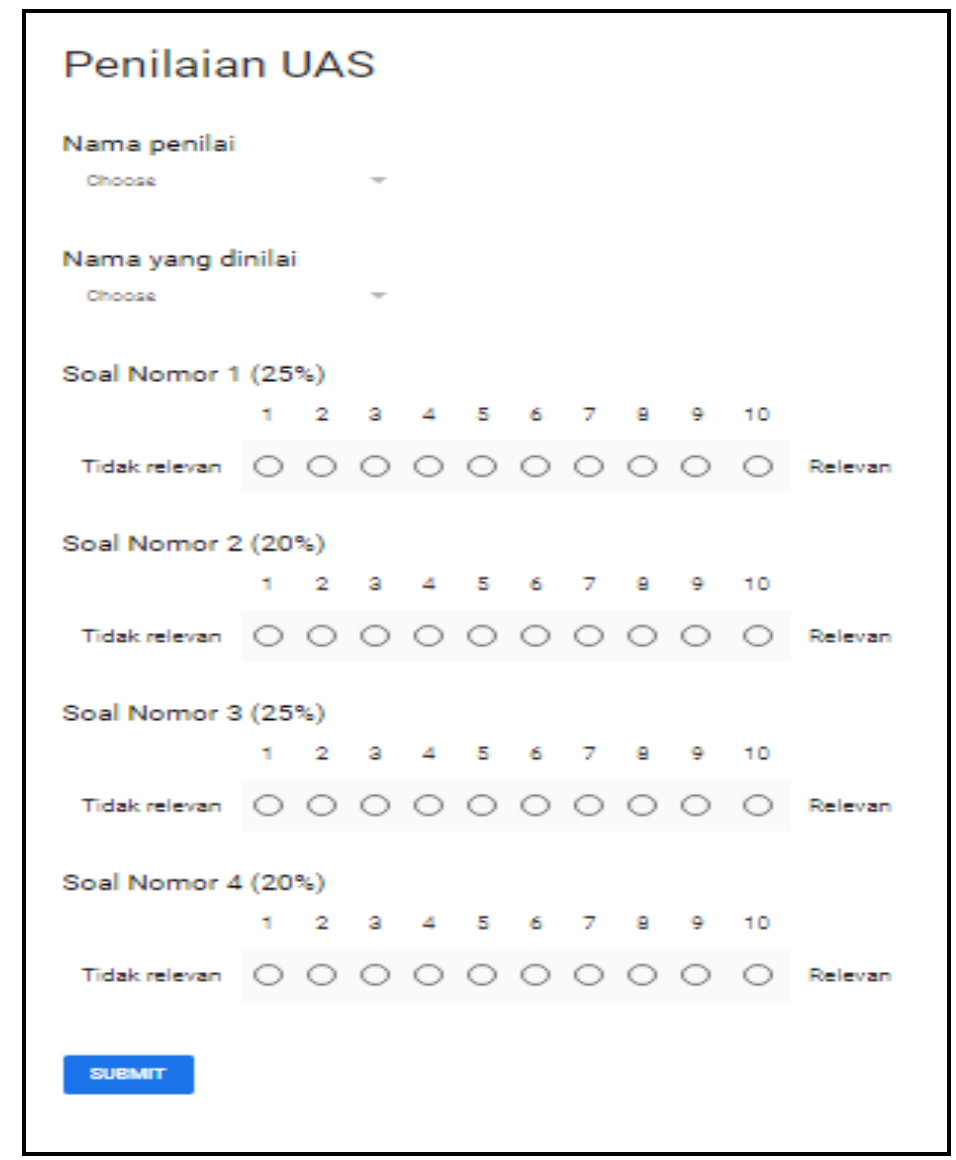

Gambar 4. Form Penilaian Teman Sejawat 
Penilaian hasil presentasi diskusi ditinjau dari penilaian makalah, powerpoint, proses presentasi diskusi dan penilaian hasil tes pasca presentasi diskusi.

\section{B. Kreativitas Mahasiswa Pada Implementasi Blended Learning Berbasis BALI}

Berdasarkan hasil penelitian menunjukkan implementasi blended learning berbasis BALI dapat menimbulkan daya kreativitas mahasiswa antara lain:

1) Mahasiswa mampu meilhat persoalan/masalah dari berbagai sudut pandang, misalnya saat membahas tentang teknologi informasi mereka mencari isu aktual penggunaan internet dan media sosial. Mereka mendiskusikan sudut pandang positif dan negatif pemanfaatan internet dan media sosial dan keterhubunganya dengan nilai-nilai Agama Hindu. Hal tersebut juga berlaku pada pembahasan tema-tema yang lainya.

2) Memiliki kemampuan berpikir menyebar jelas terlihat pada saat membahas banten Kadek Resa Yudha Lesmana (salah satu mahasiswa) bertanya "Apakah canang/banten yang dibuat oleh ibu-ibu yang sedang mengalami menstruasi, banten yang dibuatnya bias digunakan untuk sembahyang?. Hal tersebut menghasilkan diskusi yang pro kontra dengan berbagai argument dan dasar yang digunakan untuk menjawab.

3) Fleksibilitas konseptual ditunjukkan pada saat membahas perbedaan konsep jenis dan kelengkapan banten berdasarkan desa, kala, dan patra. Semua mahasiswa berusaha membawakan konsep jenis dan kelengkapan banten yang ada di daerah tempat tinggal mereka dengan daerah lain.

4) Originalitas ide sering muncul dalam diskusi misalnya saat ada ada pertanyaan "apakah perempuan yang menstruasi boleh sembahyang/ngaturang banten?". I G.N. Agus Bayu Teja menjawab bahwa sejarah kenapa orang menstruasi dinyatakan sebel karena jaman dahulu belum ada pembalut wanita sehingga darah kotor bias saja merembes sehingga tampak mengganggu secara visual bagi orang lain. Selain itu, adanya perasaan tidak nyaman dan emosi yang sesnsitif karena adanya perubahan hormonal yang dialami wanita sehingga tidak nyaman untuk sembahyang. Jika sudah menggunakan pembalut dan yang bersangkutan merasa nyaman, menstruasi tidak menjadi masalah untuk sembahyang. Sebenarnya kalau kita sadari setiap haripun semua orang membawa kotoran (feses) yang menjijikkan di perut, apakah kita semua sebel dan tidak boleh sembahyang, demikian penguatan yang diungkapkan. Sedangkan, Gusti Made Suardana memberikan jawaban yang berbeda dimana ada beberapa pura yang pingit secara niskala yang jika pantangan pura dilanggar akan mengakibatkan dampak negative bagi masyarakat sekitar atau bagi yang bersangkutan. Wanita yang sembahyang dalam kondisi menstruasi bias menyebabkan pura leteh (kotor), sehingga harus dilakukan pecaruan. Guna menengahi kedua pendapat ini maka diberikan masukan dimana pelaksanaan persembahyangan harus memperhatikan desa, kala, dan patra serta aturan yang berlaku, selain itu sebel lebih pada nilai rasa sebet (sedih/perasaan ketidaknyamanan).

5) Mahasiswa menunjukkan ketertarikan terhadap sesuatu yang kompleks dalam implementasi blended learning media berbasis tri kaya parisudha. Mahasiswa berusaha menggali lebih dalam dari berbagai persepsi yang terintegrasi terhadap isu aktual yang mereka bahas. Mulai dari isu/permasalahan, keterhubunganya dengan filosofi Agama Hindu, sampai dengan alternative solusi untuk mengatasi permasalahan yang diungkap.

6) Pengumpulan data/materi secara aktual, literatif dan integratif serta pelaksanaan presentasi diskusi merupakan lingkungan belajar yang merangsang timbulnya kreativitas individu. Khususnya saat diskusi mereka berusaha melihat dari sudut pandang yang berbeda, menerima ide yang berbeda, dan berargumentasi untuk mempertahankan idenya.

7) Blended learning media berbasis tri kaya parisudha melatih mahasiswa belajar meningkatkan berbagai keterampilan antara lain: mengungkapkan pendapat, menggunakan media presentasi power point, menggunakan google form, dan kelas maya schoology. Selain itu, keterampilan belajar aktual, literatif dan integrative meningkatkan keterampilan hidup mahasiswa untuk lebih adaptif mempelajari data, ilmu pengetahuan, dan teknologi.

Hasil penelitian ini relevan dengan hasil penelitian Luntungan (2013), Kantun \& Siswandini (2015), dan Wahyudi, dkk. (2018) menyatakan kreativitas belajar peserta didik mengalami peningkatan dengan menggunakan model Blended Learning.

\section{Motivasi Belajar Mahasiswa Pada Implementasi Blended Learning Berbasis BALI}

Motivasi belajar merupakan dorongan internal dan eksternal pada pebelajar berupa hasrat dan keinginan berhasil, dorongan dan kebutuhan dalam belajar, harapan dan cita-cita masa depan, penghargaan dalam belajar, serta lingkungan belajar yang kondusif [5]. Blended Learning Berbasis BALI 
menyediakan ruang untuk mahasiswa mengembangkan ide, keterampilan, cara belajar, kemampuan bertanya, menjawab, berargumentasi, menilai dan mengevaluasi proses pembelajaran. Mahasiswa dilibatkan secara aktif dalam keseluruhan proses pembelajaran yang mendorong motivasi belajar mahasiswa.

Bukti implementasi blended learning berbasis BALI mampu mendorong motivasi belajar mahasiwa berdasarkan munculnya indikator-indikator Schwtzgebel dan Kalb dalam Djaali (2009) antara lain:

1) Senang secara sadar dalam lingkungan atau pemberian tugas yang memerlukan tanggung jawab pribadi tanpa dasar untung rugi, nasib, atau kebetulan. Hal ini ditunjukkan dengan kesadaran mahasiwa mengikuti pembelajarn tatap muka maupun daring, pembuatan tugas yang dikumpul dan dipresentasikan tepat waktu, penilaian teman sejawat yang dilakukan berdasarkan persepsi yang mereka miliki.

2) Implementasi blended learning berbasis BALI memiliki tujuan yang ralistis dan dapat terukur yang menyasar pencapaian CPMK yang telah dirumuskan dalam RPS. Tujuan yang jelas dan realistis ini akan mendorong motivasi mahasiswa untuk belajar dan mencapai capaian mata kuliahnya.

3) Pada implementasi blended learning berbasis BALI dibentuk situasi atau proses dimana mahasiswa memperoleh umpan balik dengan segera dan nyata untuk menentukan baik atau tidaknya hasil pekerjaannya. Misalnya, setelah hasil presentasi diskusi mahasiswa diberitahu hasil penilaian teman sejawat dan dosen yang dilakukan secara online, dievaluasi kekurangan yang ada pada makalah, presentasi, jawaban dan atau argumentasi yang muncul dalam proses pembelajaran.

4) Saat pembuatan makalah dan presentasi dilakukan secara berkelompok, namun saat proses diskusi mahasiswa terihat berusaha memberikan pertanyaan dan jawaban yang dapat mengungguli mahasiswa yang lain. Tetapi dalam implementasi ini ada salah satu mahasiswi yang sangat pasif dalam proses pembelajaran khususnya dalam sesi diskusi bernama Ni Ketut Suryani. Peneliti berasumsi mahasiswi ini kurang percaya diri karena dia satu-satunya perempuan di dalam kelas, atau memang karakter dasarnya tidak suka banyak berbicara/pendiam.

\section{Simpulan dan Saran}

Berdasakan hasil penelitian dan pembahasan maka dapat disimpulkan: (1) implementasi Blended Learning berbasis BALI dilakukan melalui proses (a) persiapan tema, pembuatan kelas maya schoology, dan pembuatan form penilaian presentasi diskusi, (b) proses pembelajaran Blended Learning berbasis BALI; dan (c) penutup berupa penyimpulan dan evaluasi hasil pembelajaran; (2) implementasi Blended Learning berbasis BALI mampu mendorong kreativitas mahasiswa dengan adanya indicator-indikator deskriptif hasil pengamatan dalam proses pembelajaran; (3) implementasi Blended Learning berbasis BALI mampu mendorong motivasi belajar mahasiswa dengan teramatinya indikator sesuai dengan teori Schwtzgebel dan Kalb. Berdasarkan temuan hasil penelitian disarankan untuk peneliti selanjutnya mengggunakan subjek penelitian yang lebih banyak dengan metode yang berbeda misalnya eksperimen, penelitian tindakan, pengembangan ataupun metode campuran (mix method).

\section{Daftar Rujukan}

D. Damarjati, "Benarkah Minat Baca Orang Indonesia Serendah Ini?," 5 Januari 2019. [Online]. Available: https://news.detik.com/berita/d-4371993/benarkah-minat-baca-orang-indonesia-serendah-ini.

K. Kant, "Blended Learning: A Latest Trend in Higher Education," University News, vol. 52, no. 34, 2014.

O. Indrawan, "Transferable Skill Dan Pemahaman Konsep Pada Blended Learning Terintegrasi Tri Kaya Parisudha Pada Mata Kuliah Probstat," Jurnal Pendidikan Teknologi dan Kejuruan (JPTK), vol. 16, no. 1, pp. 1-10, 2019.

Sadirman, Interaksi dan Motivasi Belajar Mengajar, Jakarta: Raja Grafindo Persada, 2006.

H. B. Uno, Teori Motivasi dan Pengukurannya: Analisis di Bidang, Jakarta: Bumi Aksara, 2011.

Emzir, Metode Penelitian Pendidikan Kuantitatif dan Kualitatif, Jakarta: Rajawali Pers, 2015.

P. I. C. H. D. S. a. P. Kadek Cahya Dewi, "Study Of Instructional Model On Blended Learning Inpolytechnic," Cakrawala Pendidikan, pp. 270-280, 2018. 
Ali \& Anzori, Kreativitas, Kebudayaan dan Pengembangan Iptek, Bandung: PT Alfabeta, 2004.

S. B. Sjukur, "PENGARUH BLENDED LEARNING TERHADAP MOTIVASI BELAJAR DAN HASIL BELAJAR SISWA TINGKAT SMK," Jurnal Pendidikan Vokasi, pp. 368-378, 2012.

Sri Kantun \& Raras Siswandini, "Implementasi Blended Learning untuk Meningkatkan Kreativitas Dan Hasil Belajar Pada Mata Pelajaran Ekonomi Peserta Didik Kelas XI IPS-2 SMAN 5 Jember Semester Gasal Tahun 2015/2016," Jurnal Pendidikan Ekonomi, vol. 9, no. 2, pp. 141-152, 2015.

N. L. Luntungan, "Upaya Peningkatan Kreativitas Siswa Melalui Implementasi Blended Learning pada Pembelajaran Fisika Kela A SMP Negeri 1 Mantingan Tahun 2012/2013," Jurnal Pendidikan FIsika, vol. 1, no. 1, p. 64, 2013.

Wahyudi Wahyudi, Indri Anugraheni, Adi Winanto, "Pengembangan Model Blended Learning Berbasis Proyek Untuk Menunjang Kreatifitas Mahasiswa Merancang Pembelajaran Matematika Sekolah Dasar," Jurnal Ilmiah Pendidikan Matematika, vol. 6, no. 2, pp. 68-81, 2018.

Djaali, Psikologi Pendidikan, Jakarta: Bumi Aksara, 2009.

A. Farihah Manggabarani, Sugiarti, Melati Masri, "Pengaruh Model Pembelajaran Blended Learning Terhadap Motivasi dan Hasil Belajar Siswa Kelas X SMA Negeri 1 Pitumpanua Kab.Wajo," Jurnal Chemica, vol. 17, no. 2, pp. 83-93, 2016. 